\title{
Assessment of Profitability of Land Use Systems in Tanjung Jabung Barat District, Jambi Province, Indonesia
}

\author{
Muhammad Sofiyuddin, Arief Rahmanulloh, S. Suyanto \\ World Agroforestry Center (ICRAF Southeast Asia Program), Bogor, Indonesia \\ Email: m.sofiyuddin@cgiar.org
}

Received July 23 ${ }^{\text {rd }}$, 2012; Revised August 26 ${ }^{\text {th }}$, 2012; Accepted September $10^{\text {th }}, 2012$

\begin{abstract}
The purpose of the research was to compare the profitability of existing land uses in Tanjung Jabung Barat, Jambi province, Indonesia, for formulating a strategy to reduce emissions from deforestation and degradation (REDD). Net Present Value was used for comparing profits of different types of investment (e.g. different type of land use). Rapid Rural Appraisal was used to gather information on farm budget data for each land use, including prices, production, labor and other input. The results of the profitability analysis showed that all land uses, both on mineral soil and peat land, were profitable. Oil palm, both in large plantations and smallholder gardens, was the most profitable land-use system. However, the profitability of smallholder oil palm on peatland was lower than on mineral soils yet oil palm was still more competitive than rubber on mineral soils. The competitiveness of mixed gardens with oil palm was higher on peatland and the threat of converting other land uses to oil palm was higher on mineral soil than on peat. For crop systems, irrigated paddy had the highest profitability.
\end{abstract}

Keywords: Profitability; NPV; Land Use System; REDD+; Indonesia

\section{Introduction}

The purpose of the research was to compare the profitability of existing land uses in Tanjung Jabung Barat, Jambi province, Indonesia, for formulating a strategy to reduce emissions from deforestation and degradation (REDD). The results of the profitability analysis, when combined with an understanding of the carbon contents of different land uses, were crucial for assessing the trade-offs involved in different land uses. Net Present Value (NPV) was used for comparing the profits of different types of investments (e.g. different type of land use). The NPV of a project or investment is defined as the sum of the present values of the annual cash flows minus the initial investment. The annual cash flows are the net benefits (revenues minus costs) generated from the investment during its lifetime. These cash flows are discounted or adjusted by incorporating the uncertainty and time value of money (Gittinger, 1982).

\section{Study Site}

The study site was Tanjung Jabung Barat district in Jambi province on the island of Sumatra in Indonesia (Figure 1). The total area of the district was approximately $5000 \mathrm{~km}^{2}$, with almost $40 \%$ of the area being peatlands in the east towards the coast. About $48 \%$, or 240,000 ha, of the district is classified as "forest area". About $71 \%$ of the "forest area" was classified as production forest, $7 \%$ was protected peat forest and $4 \%$ was national park. The proportion of "non-forest area" in this district was very high, dominated by coconut agroforestry, rubber agroforestry, rubber monoculture and, most recently, oil palm.

The population was approximately 266,952 people in 2009, with a density of about 51 persons per square kilometer. Early in-migration occurred during the 1940s-1950s, mostly Bugis and Banjar ethnic groups from Sulawesi and Kalimantan is- lands. The most significant migration into the site occurred during the 1980s-1990s under the Government of Indonesia's transmigration program, which was linked with the development of large-scale oil palm plantations. Transmigrants were the major source of labor for oil-palm companies.

\section{Methodology}

NPV is one of the most robust financial evaluation tools to estimate the value of an investment. The formula used to calculate the NPV is:

$$
\mathrm{NPV}=\sum_{t=0}^{t=n} \frac{B_{t}-C_{t}}{(1+i)^{t}}
$$

where $B_{t}$ is benefit at year $t, C_{t}$ cost at year $t, t$ is time denoting year and $i$ is discount rate.

NPV is calculated for "private" and "social” prices. NPV at private price shows private profitability: the result can measure profitability as a production incentive. NPV at social price shows social profitability, that is, measuring the potential profit that can be received by the farmer/operator. The investment for one specific land use is considered profitable if the NPV is higher than zero. The higher the NPV the higher the profitability of an investment. An indicator of profitability is return to labor, which is defined as the wage rate at NPV equal to zero. Return to labor is calculated by adjusting the wage rate until NPV is zero. The investment is profitable if return to labor is higher than the wage rate. A rapid rural appraisal (RRA) was used to gather information on farm budget data for each land use, including prices, production, labor and input used, for 2010. The resource persons and/or key informants interviewed for the purpose of the study were farmers, traders, and government officers. 


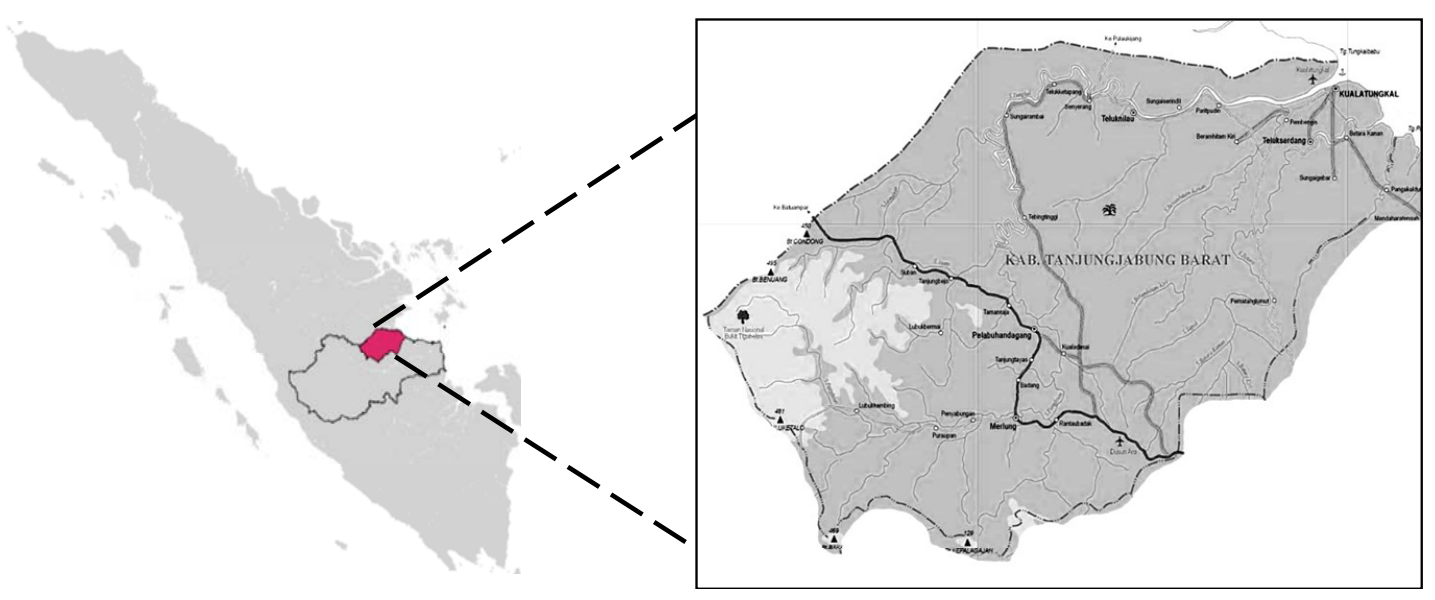

Figure 1.

Location of Tanjung Jabung Barat district, Jambi province, Sumatra Island, Indonesia.

Profitability assessment needs a detailed farm budget calculation. It is necessary to clarify the macroeconomic assumptions and the proper prices for calculating the costs and returns used in this assessment. In this study, several macroeconomic parameters were used (Table $\mathbf{1}$ ).

The wage rate for agricultural work was IDR 50,000 per day and the exchange rate was IDR 9084 to USD 1. Real interest rate (that is, interest rate net of inflation) was the discount factor used to value future cash flows in current terms. A private discount rate of $8 \%$ was chosen as the initial value of different land-use activities, being the lower boundary for the actual cost of capital for smallholders owing to imperfections in capital markets in the area. Owing to time constraints and lack of reliable time-series data, we used single-year price data, that is, 2010 prices. The analysis for this study was only undertaken at the private price. Analysis of NPV must have the same time horizon across land uses in order to remain comparable across the land uses. This study used a 30-year timeframe because we were interested in the opportunity costs of entering a REDD+ contract (White \& Minang, 2011).

\section{Result of the Assessment}

The first step in the study was to select land uses for profitability analysis. We divided land uses into eight: forest, Acacia mangium, oil palm, coconut, rubber, coffee, betel nut, and crops. In Tanjung Jabung Barat, there was a further divide into two soil classifications: mineral and peat. Land-use systems were also classified into large and small scale. Therefore, 15 land-use systems were selected for profitability analysis (Table 2).

For large-scale operations, there were forest concessions, industrial timber plantations (Acacia mangium), and oil palm plantations. All large-scale land-use systems were on mineral soil. For smallholding operations, the study selected smallholders' oil palm, rubber (monoculture and mixed systems), coconut (monoculture and mixed systems), coffee (mixed systems), and betel nut (mixed systems) to be assessed. On mineral soil, the dominate land-use system was smallholding oil palm and rubber, both monoculture and mixed. On peat, the dominant system was mixed gardens: coconut, coffee, and betel nut. Agriculture was divided into irrigated paddy, dryland paddy on mineral soil, tidal paddy, and maize on peat soil.

\section{Profitability of Different Type of Land Use Systems}

The results of the profitability analysis showed that all land uses, both on mineral soil and peat, were positive, indicating that those land uses were profitable. Estimates of NPV evaluated at private price are presented in Table 3.

Large-scale oil palm plantation on mineral soil was the most profitable land use. Indonesia has high comparative advantage in oil palm. Since 2007, Indonesia has been the world's largest palm oil producer. The development of oil palm in Indonesia was fast, with the area of plantations increasing from 120,000 ha in 1969 to almost 8 million ha in 2010. Indonesia now controls more than $45 \%$ of the world's palm oil market share (Dirjenbun, 2009). Therefore, it is not surprising that Indonesian oil palm development continues to increase: business is very profitable for both companies and the state.

Jambi province is currently the fourth largest in total area under oil palm plantations in Indonesia, covering approximately 550,000 ha. Tanjung Jabung Barat district provides 15\% of this, at around 84,614 ha (BPS, 2010). More than 75\% is dominated by large-scale oil palm plantations, with approximately 12 private oil palm plantations in Tanjung Jabung Barat, consuming a total area of about 60,000 ha (BKPM, 2011).

Large-scale logging also has high NPV but is still lower than an oil-palm system. Although there are no more forest concessions in Tanjung Jabung Barat, large-scale conversion of forests and logged-over forests began for the development of industrial tree and oil palm plantations. This is the dilemma: high profitability from logging will cause people to deplete the forest resource but low profitability will encourage conversion of forests to other land uses that are more profitable.

Table 1.

Macroeconomic parameters used in the study.

\begin{tabular}{ll}
\hline Parameters & 2010 \\
\hline Exchange rate & IDR 9084/ USD 1 \\
Wage rate in Jambi & USD 5.5 per person per day \\
Real interest rates (net of inflation) & \\
Private & 8\% per year \\
\hline
\end{tabular}


Table 2.

Land cover of Tanjung Jabung Barat and the selected main land-use systems.

\begin{tabular}{|c|c|c|c|}
\hline \multirow{2}{*}{ Land-cover type } & \multicolumn{2}{|l|}{ Selected land-use system } & \multirow{2}{*}{ Scale of operation } \\
\hline & On mineral & On peat & \\
\hline Forest & $\begin{array}{l}\text { Forest extraction. Logging (low density) } \\
\left(17 \mathrm{~m}^{3} / \mathrm{ha}\right)(45,000 \mathrm{ha})\end{array}$ & $\mathrm{n} / \mathrm{a}$ & \\
\hline Acacia mangium & $\begin{array}{l}\text { Industrial timber plantation (Acacia mangium) } \\
(12,274 \text { ha) }\end{array}$ & $\mathrm{n} / \mathrm{a}$ & Large-scale enterprises \\
\hline Oil palm & Oil palm (3000 ha) & $\mathrm{n} / \mathrm{a}$ & \\
\hline Oil palm (1 - 2 ha) & $\begin{array}{l}\text { Nucleus estate and smallholder (NES) } \\
\text { Oil palm }\end{array}$ & Independent smallholding & \\
\hline Coconut (1 - 2 ha) & Coconut monoculture & $\begin{array}{l}\text { Coconut-based mixed garden (with coffee and } \\
\text { betel nut) }\end{array}$ & Smallholdings \\
\hline Rubber (1 - 2 ha) & Rubber monoculture & Rubber monoculture rubber agroforest & \\
\hline Coffee (1 - 2 ha) & $\mathrm{n} / \mathrm{a}$ & Coffee-based mixed garden (with betel nut) & \\
\hline
\end{tabular}

Table 3.

Private profitability of land use systems in Tanjung Jabung Barat.

\begin{tabular}{|c|c|c|c|}
\hline No & Land Use System & $\begin{array}{l}\text { NPV on Mineral } \\
\text { (USD/ha) }\end{array}$ & $\begin{array}{l}\text { NPV on Peat } \\
\text { (USD/ha) }\end{array}$ \\
\hline \multicolumn{4}{|c|}{ Large Scale } \\
\hline 1 & Oil palm large scale & 7615 & - \\
\hline 2 & Logging & 6114 & - \\
\hline 3 & Acacia plantation & 1040 & - \\
\hline \multicolumn{4}{|c|}{ Smallholder } \\
\hline 4 & Smallholder oil palm & 7012 & 5866 \\
\hline 5 & Rubber monoculture & 2417 & 1481 \\
\hline 6 & Rubber agroforest & 1580 & - \\
\hline 7 & Coconut monoculture & 734 & - \\
\hline 8 & $\begin{array}{l}\text { Coffee agroforest with } \\
\text { betel nut }\end{array}$ & - & 5722 \\
\hline 9 & $\begin{array}{l}\text { Coconut agroforest with } \\
\text { coffee and betel nut }\end{array}$ & - & 5301 \\
\hline 10 & $\begin{array}{l}\text { Betel nut agroforest with } \\
\text { coconut }\end{array}$ & - & 2002 \\
\hline 11 & Jelutung monoculture & - & 3590 \\
\hline \multicolumn{4}{|c|}{ Crops } \\
\hline 12 & Dryland paddy & 404 & - \\
\hline 13 & Irrigated paddy & 974 & - \\
\hline 14 & Tidal paddy & - & 882 \\
\hline 15 & Maize & - & 595 \\
\hline
\end{tabular}

Acacia plantations also have a positive NPV but it is not as high as the NPV of oil palm and logging. The development of industrial timber plantations became part of the strategy for national development to satisfy the demand for raw material from the wood pulp industry. Nine million hectare were targeted for development in 2011 but the realization was only $45 \%$ in 2010 (Dirjen BPK, 2010). The low NPV for acacia plantations indicates that indeed this business is not very attractive for investors and farmers. Acacia plantations have a high establishment cost: major costs are associated with establishing and maintaining roads and infrastructure, and tax payments to the national and local governments.

All smallholders' land-use systems showed positive profitability, with oil palm having the higher profitability, both on mineral and peat. Once again, this shows that whatever the management system, oil palm is a very attractive option. Smallholders' rubber plantations also showed positive profitability, but about only half that of oil palm. On mineral soil, many farmers changed their rubber systems to oil palm. The entry of large plantation companies also influenced this decision. Large-scale oil palm plantation sites in Tanjung Jabung Barat were mostly scattered in Tungkal Ulu and Merlung sub-districts and are all on mineral soil (BPS, 2010).

If we compare smallholders' land-use systems on mineral and peat, the results show that mineral soil is more profitable than on peat. Management systems on peat for all land-use system are more complex: there are additional costs for the construction and maintenance of the drainage system (parit). The costs are required continuously throughout the year for maintenance to prevent submersion of plants and trees, which can succumb to acid poisoning from the peat water. And instead of drowning, excess water will cause plants to die of thirst. For oil palm on peat, the difficulty of market access causes low prices for fresh fruit bunches.

In the past, coconut plantations in peat areas were monocultural. However, since the 1990s the price of coconut has declined. Thus, farmers started to intercrop with coffee and betel nut (called "mixed gardens") to increase their profits. Profitability of the mixed garden system was nearly equal to oil palm plantations on peat. In other word, the competitiveness of mixed gardens against oil palm was high.

Another land-use system in Tanjung Jabung Barat that must be considered is "jelutung" (Dyera sp.) monoculture plantations. This is a program of the forestry office in Tanjung Jabung Barat that was initiated to protect forests on peat (HLG). About 4600 
ha from a total 16,000 ha has been encroached (Dishut, 2008). Owing to limited data, this study used previous research data adjusted to the conditions in Tanjung Jabung Barat. Because the jelutung was planted, there is no farm budget data available. Hence, in this study we used prediction data from another study. Jelutung was planted at spacings of $5 \times 5 \mathrm{~m}$, so in one hectare there were 400 tress (Rahmat \& Bastomi, 2007). The results showed that the private profitability of jelutung is lower than mixed gardens and oil palm plantations.

The result from crop systems shows that the profitability is lower than other land-use systems. Irrigated paddy had the highest profitability, with the use of fertilizer having a major impact on productivity. Dryland paddy had lower profitability for crop systems, with simple management affecting the low results.

Table 4 shows the results of return to labor. The return to labor for all land-use systems shows a larger value than the wage rates in Tanjung Jabung Barat, which was on average USD 5.5 per person per day. This suggests all land uses were attractive and profitable for farmers and operators.

In large-scale systems, return to labor at the private rate was in the range USD 8 - 17 per person per day. Acacia plantations had a higher return to labor. Interestingly, although the value of

Table 4.

Private return to labor for all land use systems in Tanjung Jabung Barat.

\begin{tabular}{|c|c|c|c|}
\hline No & Land Use System & $\begin{array}{l}\text { Return to Labor } \\
\text { on Mineral } \\
\text { (USD/person per } \\
\text { day) }\end{array}$ & $\begin{array}{l}\text { Return to Labor } \\
\text { on Peat } \\
\text { (USD/person per } \\
\text { day) }\end{array}$ \\
\hline \multicolumn{4}{|c|}{ Large Scale } \\
\hline 1 & Oil palm large scale & 12.39 & - \\
\hline 2 & Logging & 8.47 & - \\
\hline 3 & Acacia plantation & 17.07 & - \\
\hline \multicolumn{4}{|c|}{ Smallholdings } \\
\hline 4 & Smallholder oil palm & 17.29 & 16.06 \\
\hline 5 & Rubber monoculture & 7.39 & 8.05 \\
\hline 6 & Rubber agroforest & 7.09 & - \\
\hline 7 & Coconut monoculture & 8.93 & - \\
\hline 8 & $\begin{array}{l}\text { Coffee agroforest with } \\
\text { betel nut }\end{array}$ & - & 8.91 \\
\hline 9 & $\begin{array}{l}\text { Coconut agroforest } \\
\text { with coffee and betel } \\
\text { nut }\end{array}$ & - & 8.54 \\
\hline 10 & $\begin{array}{l}\text { Betel nut agroforest } \\
\text { with coconut }\end{array}$ & - & 7.75 \\
\hline 11 & Jelutung monoculture & - & 16.46 \\
\hline \multicolumn{4}{|c|}{ Crops } \\
\hline 12 & Dry land paddy & 5.83 & - \\
\hline 13 & Irrigated paddy & 7.04 & - \\
\hline 14 & Tidal paddy & - & 6.19 \\
\hline 15 & Maize & - & 6.96 \\
\hline
\end{tabular}

return to labor is quite large for acacia plantations, the system has the lowest NPV compared with other large-scale systems. This is related to the very high amount of labor required for the establishment and operational phases. Acacia plantations also did not have a positive cash flow until after years 10 of management. This shows that the land-use system was not efficient. The same happened with jelutung monoculture plantations, which meant that this system was also not efficient. This differed from oil palm plantation, both large-scale and smallholdings, which have a high NPV and return to labor, showing that the system is very efficient, attractive and profitable.

For smallholders' systems the return to labor ranged USD 7 17 per person per day. Oil palm on mineral soil had a higher return to land and rubber agroforest was the lowest for smallholders' systems. This result indicates the reason why farmers switch from rubber to oil palm. Return to labor is an indicator of profitability for farmers, which is the incentive to production. High return to labor tends to encourage local people to switch to, and commercialize, this land-use system.

For crop systems, the return to labor ranged USD 5 - 8 per person per day. Irrigated paddy had the highest return to labor. Although it was lower than other land-use systems the value was still higher than the wage rate in Tanjung Jabung Barat.

\section{Conclusion}

The results of profitability analysis showed that all land uses both on mineral soil and peat are profitable. There are several highlights of this study.

- Large scale oil palm was the most profitable land use system.

- Of the smallholders' systems, oil palm was the most profitable. Oil palm on peat was lower than on mineral soil because of higher costs in establishing drainage systems and lower productivity.

- The competitiveness of rubber was lower against oil palm on mineral soil. The profitability of smallholders' oil palm was almost three times that of rubber.

- The competitiveness of mixed gardens was high against oil palm on peat. The profitability of mixed gardens was almost the same as oil palm.

- The threat of converting other land uses to oil palm was higher on mineral soil than on peat.

- Crop systems had lower profitability than other land-use systems. Of crop systems, irrigated paddy had the highest profitability.

\section{Acknowledgements}

The authors would like to thank the communities of Tanjung Jabung Barat district for their generous hospitality and their patient participation in the surveys. This study was part of two complementary research projects: the NORAD-funded project, "Reducing Emissions from All Land Uses (REALU)" and the European Union-funded project, “Accountability and Local Level Initiatives to Reduce Emissions from Deforestation and Degradation (ALLREDDI)”.

\section{REFERENCES}

Astana, S. (2005). Analysis of log export policy from Acacia plantation. Bogor: Pusat Penelitian Sosial Ekonomi dan Kebijakan Kehutanan. 


\section{SOFIYUDDIN ET AL.}

Badan Koordinasi Penanaman Modal (BKPM) (2011). Profile of Tanjung Jabung Barat district. URL (last checked 15 June 2012).

http://regionalinvestment.com/newsipid/komoditipelakuusaha.php?ia $=1507 \&$ is $=122 \&$ rowPerPage $=10$ \&hlm $=1$

Badan Pusat Statistik (BPS) (2010). Tanjung Jabung Barat in figures. Jambi: Badan Pusat Statistik.

Chambers, R., Pacey, A., \& Trupp, L. A. (1989). Farmer first: Farmer innovation and agricultural research. London: Longman.

Direktorat Jendral Bina Produksi Kehutanan (Dirjen BPK) (2009). Forest plantation development policy. Jakarta: Kementrian Pertanian.

Direktorat Jendral Perkebunan (Dirjenbun) (2009). National oil palm development, realizing the vision of Indonesia in 2020. URL (last checked 15 June 2012).

http://ditjenbun.deptan.go.id/index.php?option=com_content\&view= article\&id=85:pengembangan-kelapa-sawit-nasional-mewujudkan-

visi-indonesia-2020\&catid=36:news
Direktorat Jendral Perkebunan (Dirjenbun) (2010). Tree crop estate statistics. Jakarta: Kementrian Pertanian.

Dinas Kehutanan Provinsi (Dishut) (2008). The design of forest production management unit in Jambi province. Jambi: Dinas Kehutanan Provinsi.

Gittinger, J. P. (1982). Economic analysis of agricultural projects (2nd ed.). Baltimore: Johns Hopkins University Press.

Monke, E., \& Pearson, S. R. (1989). The policy analysis matrix for agricultural development. New York: Cornell University Press.

Rahmat, M., \& Bastomi (2007). Financial feasibility of replacement tree for sonor cultivation. Bogor: Pusat Penelitian Sosial Ekonomi dan Kebijakan Kehutanan.

Utomo, N. A. (2002). Potential development and marketing of betel nut. Thesis, Bogor: Bogor Agriculture Institute.

White, D., \& Minang, P. (2011). Estimating the opportunity cost of $R E D D+$, training manual. Washington: World Bank. 